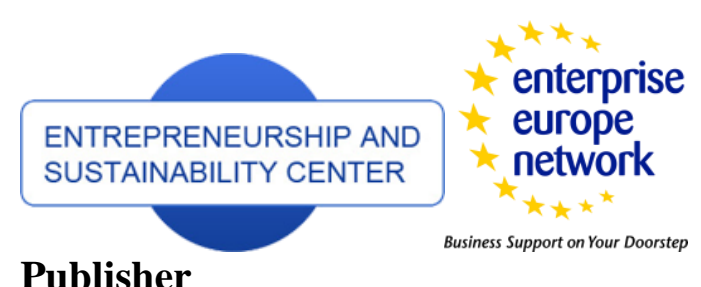

Publisher

http://jssidoi.org/esc/home

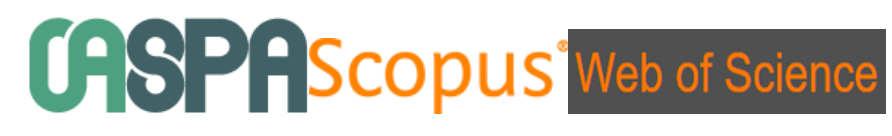

1 Clarivate

\title{
MONITORING OF INDUSTRIAL ENTERPRISES' PERFORMANCE IN EMERGING ECONOMY: A CASE STUDY
}

\author{
Ainur Karipova ${ }^{1}$, Kabdullina Gulmira ${ }^{2}$, Gizat Kenesheva ${ }^{3}$, Madina Tursumbaeva $^{4}$, \\ Saltanat Kapysheva ${ }^{5}$, Zhanna Nurgalieva ${ }^{6}$ \\ ${ }^{1}$ Gumilyov Eurasian National University, Nur-Sultan, Kazakhstan \\ ${ }^{2}$ South Ural State University, Russian Federation \\ ${ }^{3}$ Karaganda Economic University of Kazpotrebsoyuz, Karaganda, Kzakhstan \\ ${ }^{4,5,6}$ Kazakh University of Economics, Finance and International Trade, Nur-Sultan, Kazakhstan \\ E-mails: ${ }^{1}$ karipovaainur@mail.ru; ${ }^{2}$ Asilhan1996@mail.ru; ${ }^{3}$ gizzat@yandex.ru; ${ }^{4}$ tursumbaeva_m@mail.ru; \\ 5saltik_ksk@mail.ru; ${ }^{6}$ zhannanurgali@mail.ru
}

Received 15 February 2020; accepted 18 October 2020; published 30 December 2020

\begin{abstract}
Business monitoring and reporting issues receive close attention. Nationalization of indicators, creation of a statistical database, determination of data sources and methodology for their calculation are in the priority of state policy, especially in a crisis, when enterprises are required to improve production efficiency, competitiveness and effective forms of management in production management. An important role in the implementation of this task is assigned to monitoring the financial condition of enterprises, since it is one of the most effective methods for diagnosing the economic activity of enterprises. Analytical materials prepared during the monitoring process help to carry out a comprehensive analysis and forecast of the financial position of the enterprise and, thereby, to obtain a real assessment of the enterprise's capabilities. The article examines the current state of industry in Kazakhstan, analyzes the problems hindering its development, presents the author's vision of their solution. On the basis of modern scientific and applied literature, various approaches to the formation of the concepts of financial monitoring, methods of analyzing the financial condition of an organization are widely presented.
\end{abstract}

Keywords:innovation; industry; investment; monitoring; accounts receivable; profit; loss; Kazakhstan

Reference to this paper should be made as follows: Karipova, A., Gulmira, K., Kenesheva, G., Tursumbaeva, M., Kapysheva, S., Nurgalieva, Zh. 2020. Monitoring of industrial enterprises' performance in emerging economy: a case study. Entrepreneurship and Sustainability Issues, 8(2), 1177-1196. http://doi.org/10.9770/jesi.2020.8.2(70)

JEL Classifications: M21, O21 


\section{ENTREPRENEURSHIP AND SUSTAINABILITY ISSUES}

ISSN 2345-0282 (online) http://jssidoi.org/jesi/

2020 Volume 8 Number 2 (December)

http://doi.org/10.9770/jesi.2020.8.2(70)

Make your research more visible, join the Twitter account of ENTREPRENEURSHIP AND SUSTAINABILITY ISSUES:@Entrepr69728810

\section{Introduction}

Over the years of independence, Kazakhstan, being a rapidly emerging economy, has implemented a number of systemic and structural economic reforms and carried out large-scale privatization. Free development of entrepreneurship has shaped the economy, which has provided real growth in the welfare of citizens. As a result, by the middle of the first decade of the new century, Kazakhstan became one of the most dynamically developing countries in the world. This was also facilitated by the favorable conjuncture of the global resource market, which ensured a rapid growth in production, an increase in the level of income of the population and social transfers, and the formation of a middle class.

The country has now accelerated the transition to diversified economic growth, where efforts and resources are concentrated on a limited number of sectors, taking into account regional specialization and the application of a cluster approach. In the future, it is planned to converge the policy of territorial and industrial development. Kazakhstan has taken a course towards increasing the productivity and complexity of the economy, developing human capital, strengthening the role of the private sector, which will allow the country to overcome the "middle income trap" and reach a new level of development.

Despite the favorable dynamics of industrial development in 2019 , the impact of the global financial crisis, as a result of the pandemic, had an impact on the economy. Despite some indicators of economic recovery, there is still uncertainty about future economic growth, availability of capital, as well as the cost of capital, which could negatively affect the company's financial position, results of operations and economic prospects (N.S., Jiran, H., Gholami, S., Mahmood, M.Z.M., Saman, N.M.,Yusof, V., Draskovic, R. Javovic, 2019). Although the management and management of the companies are confident that they are taking appropriate measures to maintain the sustainability of the company in the current environment, an unexpected further deterioration could have a negative impact on the financial results and financial position of the company's industries. The experience of developed countries has shown that in the conditions of an unstable economic situation and heightened competition, the presence of an effective mechanism for monitoring the financial condition in a company becomes an essential condition for the stable and successful development of a company. Forming operational information on the basis of systematic analysis, monitoring provides the basis for making optimal management decisions, assessing their consequences even before implementation and predicting the further development of the organization.Crisis phenomena in the world economy require industrial enterprises to increase production efficiency, competitiveness, and effective forms of management and production management. An important role in the implementation of this task is assigned to monitoring the financial condition of enterprises, since it is one of the most effective methods for diagnosing the economic activity of enterprises. Analytical materials prepared during the monitoring process help to carry out a comprehensive analysis and forecast of the financial position of the enterprise and, thereby, to obtain a real assessment of the enterprise's capabilities. In Kazakhstan, the collection of information and analysis of the state of development of entrepreneurship and the business climate is carried out mainly according to the data of international rating agencies, which reflect indicators only at the republican level, as well as on the basis of the results of market surveys, which are one of the forms of statistical observations. But as a process of constant monitoring in order to identify the compliance of the development of entrepreneurship with the set tasks, it is practically not carried out either at the sectoral or at the regional levels.

Currently, in Kazakhstan, monitoring of the main financial and economic indicators of enterprises is carried out by various government agencies. The Committee on Statistics monitors the main indicators of large and medium-sized enterprises, prepares and publishes monthly statistical data characterizing the main indicators of the financial and economic activities of medium and large enterprises by type of economic activity: income from sales of products 


\section{ENTREPRENEURSHIP AND SUSTAINABILITY ISSUES}

ISSN 2345-0282 (online) http://jssidoi.org/jesi/

2020 Volume 8 Number 2 (December)

http://doi.org/10.9770/jesi.2020.8.2(70)

Make your research more visible, join the Twitter account of ENTREPRENEURSHIP AND SUSTAINABILITY ISSUES:@Entrepr69728810

and services, cost of goods sold and services rendered, non-production expenses, profit (loss) before taxation, profitability (loss ratio) of production. It also publishes monthly information on the state of mutual settlements of enterprises by type of economic activity, quarterly dynamics of accounts receivable and liabilities of large and medium-sized enterprises, dynamics of financial results, share distribution of enterprises that received income and loss for a certain quarter.Research conducted by government agencies allows to obtain mainly statistical data, analytical results characterizing the most important market indicators, and does not provide complete information to assess the financial condition of the enterprises under study, that is, the monitoring carried out by these organizations, the co-organizers, does not provide funding.Thus, for a more complete diagnosis, timely detection of crisis situations in the economy, external state monitoring of the financial condition of enterprises is required.At present, the state exercises only control over the bankruptcy procedure of insolvent enterprises. Analysis of trends at the enterprise level in the production of goods, services and aggregation at the macro level allows reinforcing dynamics and improving forecasting of macro indicators.

\section{Literature review}

According to the research of M.A. Batkovsky, P.V. Kravchuk (2019) the problems of creating a system for monitoring the activities of enterprises are due to the insufficient development of the scientific and methodological base for monitoring the activities of enterprises, since at present, there is no generally accepted concept of it, a unified terminology, etc., which reduces the effectiveness of monitoring in practice. When introducing a monitoring system for the activity of an innovatively active enterprise, the problem of determining the basic principles of creating this system is acute. Based on the analysis of various sources and practice of creating monitoring systems Yu.S. Shiryaeva, L.N. Pertseva, E.N. Lapshina, E.A. Lapshin (2017) propose to use principles that significantly increase the level of decision-making risk in the process of introducing a monitoring system at innovative-active enterprises.Many aspects related to the justification of assessment methods and ways to increase the potential of the enterprise are poorly studied and insufficiently researched. In this connection, there is a need to search for a methodology for assessing the economic potential of an enterprise that allows it to function effectively in market conditions (Dzhamay, 2017). According to M.A. Soldatova, L.E. Lazarenko, O.A. Stepanova (2015) industrial enterprises, especially those that are private property, carry out their activities not only in their own interests, but also in the interests of shareholders, which imposes certain requirements on the management system, including on the system for monitoring the economic condition, since it is precisely on the reliability and timeliness of providing information about the functioning of the enterprise depends on the effectiveness of management activities. The analysis of the main models for the formation of competitive advantages made it possible to formulate a hypothesis about the advisability of applying a systematic approach to assessing the factors influencing strategic behavior. The basis for modeling assessment methods is the field of monitoring the strategic potential, which consists of the coordinate planes of the assessment of elements that allow forming the strategic potential of industrial enterprises as the uncertainty of the business environment, the efficiency of the business network, and integration potential.V. Zhuravlyov, T. Khudyakova, N. Varkova, S. Aliukov, S. Shmidt (2019) improved and proposed model that determines the interdependence between the strategic management of investment policy and sustainable economic development of the company, which represents an algorithm for managing the process of developing investment strategies in industry. Many scientists propose methods for monitoring the sustainable development of industrial enterprises (P. Chowdhury, Paul Sanjoy, K., 2020). So, E.A.Tretyakova, T.V. Alferova (2016) proposed a methodology for assessing the level of sustainable development, implemented in the algorithm and a group of indicators of the enterprise. The calculation of single indicators of sustainable development in the economic, environmental and social spheres was carried out, then in statics - the determination of their normalized values, in dynamics - the calculation of the rate of their change and the construction of dynamic standards with their use. The calculation of group static and dynamic indices for each sphere and the calculation of integral static and dynamic 


\section{ENTREPRENEURSHIP AND SUSTAINABILITY ISSUES}

ISSN 2345-0282 (online) http://jssidoi.org/jesi/

2020 Volume 8 Number 2 (December)

http://doi.org/10.9770/jesi.2020.8.2(70)

Make your research more visible, join the Twitter account of ENTREPRENEURSHIP AND SUSTAINABILITY ISSUES:@Entrepr69728810

indices were made. Combining static and dynamic assessments made it possible to display the trajectory of movement of the positions of each of the enterprises in the matrix of complex assessment of the level of sustainable development of an industrial enterprise.Many scientists pay special attention to the analysis of information sources to assess the innovative potential, where they analyze the existing forms of statistical reporting and propose indicators that need to be obtained, where the decision-making methods that provide information, psychological, social and economic security of the information technology implementation process are taken as a basis (Bogatenkov, Belevitin, Khasanova, 2018). Many scientists propose methods for monitoring the sustainable development of industrial enterprises. So, A. Limp, A. Loureiro Rezende, A.Versian (2018) and A.N., Neculaesei, M., Tatarusanu, B., Anastasiei, N., Dospinescu, M.V., Bedrule Grigoruta, A.M. Ionescu, (2019) proposed a methodology for assessing the level of sustainable development, implemented in the algorithm and a group of indicators of the enterprise. H. Cuevas-Vargas, N. Parga-Montoya, R. Fernández-Escobedo (2016) in their research paid special attention to the analysis of information sources to assess the innovative potential, where he analyzes the existing forms of statistical reporting and offers indicators that must be obtained through a survey of companies.

Monitoring the financial condition is one of the most important functions of financial management to assess (analyze) the availability, placement and use of the company's financial resources. Monitoring is a mechanism for financial managers to constantly monitor the most important current results of the company's financial activities in the context of constantly changing market conditions. When forming a monitoring system, it is necessary to highlight the monitoring object, that is, the object being monitored in order to control its financial condition, and the monitoring subject, which will directly monitor and evaluate the results. The concept of "monitoring" entered the scientific literature relatively recently - at the beginning of the 70s. XX century this term has been studied for a long time in relation to environmental problems. The term "monitoring" was used in connection with the processing of information about the state of the environment as a system of observation and control over changes in the natural environment as a result of human economic activity. With the development of market relations in the post-Soviet space, works appeared on the problems of monitoring in the economic sphere.Monitoring is a means and methods of control and supervision over the course of any processes or commercial activities of an enterprise, carried out by an entrepreneur in order to stabilize production parameters". The study of the issues of monitoring the financial condition of enterprises was developed in the works of many authors, e.g. A.B. Rakhimbaev, E.E. Mikhel (2016).According to V.V. Kovalev (2015), monitoring is understood as continuous observation of economic objects, the analysis of their activities as an integral part of management. Such scientists as e.g. T. U. Turmanidze(2015),S. Hilkevics, V. Semakina, V. (2019) in their works also touched upon certain aspects of monitoring the financial condition of the company. In their opinion, monitoring the financial condition of a company is a system for monitoring, analyzing and evaluating the financial condition of a company in order to identify trends, forecast development prospects, prevent crisis situations and make optimal management decisions.

E.N. Barikayev (2015) notes that the main goal of monitoring the financial condition is the timely identification of trends in the financial condition of the company and the assessment of development prospects.

V. Akulov, M. Rudakov (2015) and V. Branichev (2018) highlight the main tasks of monitoring the financial condition of the company:

- determination of the main financial indicators of the company for a certain period and their trends;

- analysis and evaluation of the results obtained;

- assessment of the effectiveness of the company's financial policy;

- timely identification and analysis of negative trends in the company's financial condition, assessment of the company's financial risks;

- prevention of crisis situations;

- forecasting the company's activities; 


\section{ENTREPRENEURSHIP AND SUSTAINABILITY ISSUES}

ISSN 2345-0282 (online) http://jssidoi.org/jesi/

2020 Volume 8 Number 2 (December)

http://doi.org/10.9770/jesi.2020.8.2(70)

Make your research more visible, join the Twitter account of ENTREPRENEURSHIP AND SUSTAINABILITY ISSUES:@Entrepr69728810

- justification of recommendations and proposals for improving the financial stability of the company, identifying reserves.

So, from the position of V.P. Gruzinov, V.D. Gribov (2015) monitoring of the financial condition of an organization, assessment of its solvency are a prerequisite for the implementation of state policy aimed at preventing the bankruptcy of organizations (enterprises), at financial recovery and restructuring of insolvency.According to K.I. Polikarpov (2018) the concept of "monitoring" is much broader than the concept of "analysis". Monitoring includes analysis, as one of the main stages of its implementation. K. Zhakisheva (2018) believes that financial monitoring (monitoring of financial condition) is a system of continuous control and analysis of the financial condition and results of the organization's work.Soldatova, M., Lazarenko, L., Stepanova, O. (2015) consider financial monitoring as a system of continuous monitoring, analysis and forecasting of indicators of the financial condition of enterprises, formed at the macro- or microeconomic levels, in order to ensure the adoption of tactical and strategic management decisions at the appropriate level, as well as to assess the effectiveness of decisions.M.M. Berdar also did not distinguish between the concepts of "financial analysis" and "financial monitoring". They note that based on the results of monitoring studies of various aspects of the enterprise's activities, managers and owners have the opportunity to start developing a reflexive model for the financial recovery of the enterprise.From the position of T. Grynko, O. Krupskyi (2017) monitoring the financial condition of organizations is a system of continuous monitoring of the financial condition, including the prompt collection of information, analysis of key financial indicators and the adoption, based on the analysis results, of management decisions of a preventive and prophylactic nature.Many authors believe that monitoring the financial condition of an enterprise is the most important tool for anti-crisis management of an enterprise. Thus, scientists A. Abeldanova, Z. Smailova (2017), R. Berstembaeva (2017), D. Tleuzhanova, N. Yemelina, A. Omarova (2018) believe that the implementation of constant monitoring the financial condition of an enterprise is a prerequisite for early detection of the symptoms of a financial crisis.From the point of view of other authors, monitoring of the financial condition of an enterprise is a system of continuous monitoring, analysis and assessment of the financial condition of an enterprise based on key financial indicators in order to identify trends, forecast development prospects, prevent crisis situations and make optimal management decisions (A. Babaytsev, E. Kuznetsova, L. Rabinskiy, O. Tushavina, 2020).Thus, the monitoring system should have a signaling, warning character, the essence of which is to identify, as a result of systematic diagnostics of the financial condition, the likelihood of insolvency or bankruptcy of enterprises.

\section{Research questions}

Monitoring the innovative potential of industrial enterprises and their innovative activity in the context of the development of competition and globalization of world commodity markets is of particular importance for the future development of the industry and industry of the country as a whole. When monitoring enterprises, a large number of different economic and financial indicators are analyzed. Some of the indicators are accessible and determine the activities of companies and the industry as a whole. Access to other indicators requires the maximum transparency of enterprise management.

Developing policies to create the conditions for balanced, environmentally friendly growth requires an understanding of the drivers of economic development, with due regard to sustainability, economic and social wellbeing. Responsible policymakers need information to monitor progress, plan future directions and evaluate results. Information, reflecting internationally comparable data and indicators, serves as a basis for developing new policies and promoting ideas and strategies.

Kazakhstan's introduction of a methodology for measuring and monitoring the progress of industrial enterprises allows for increased international cooperation, which means the dissemination of knowledge, exchange of 
Make your research more visible, join the Twitter account of ENTREPRENEURSHIP AND SUSTAINABILITY ISSUES:@Entrepr69728810

information and the development of common approaches to sustainable growth. Effective monitoring and evaluation requires more than data. It is also necessary to build institutional capacity, clarify the functions of various government structures, create new state bodies as necessary and support research activities at the national level within the framework of policy priorities and measures for the development of industries in the Republic of Kazakhstan. Research questions raised in the paper are presented graphically below (see Figure 1).

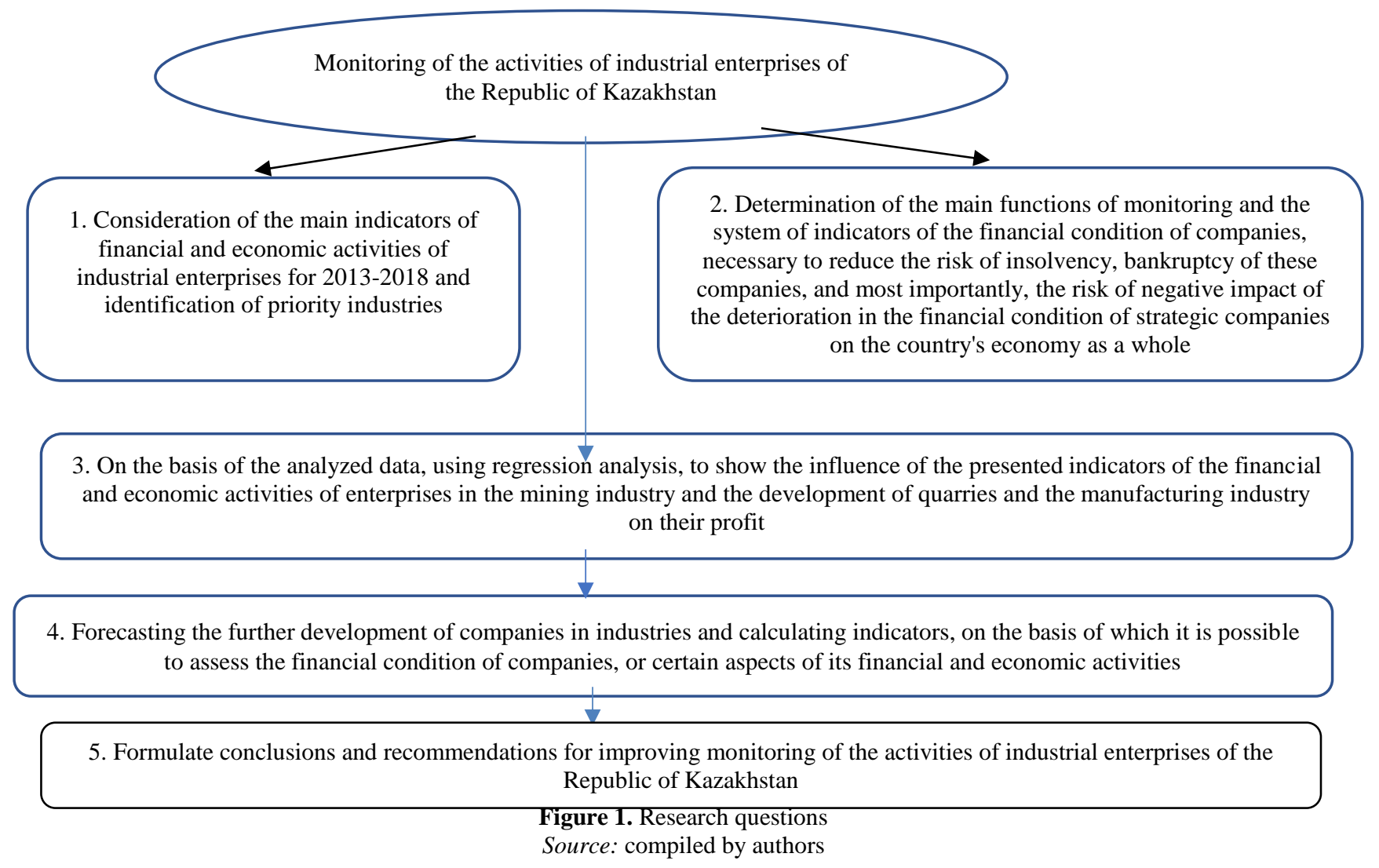

\section{Analysis and results of the research}

At present, industry occupies almost one third of the structure of the economy of Kazakhstan. A high share of the mining sector provides more than $2.5 \%$ of employment and an average of $26.6 \%$ of GVA in the economy (Table 1). 


\section{ENTREPRENEURSHIP AND SUSTAINABILITY ISSUES}

ISSN 2345-0282 (online) http://jssidoi.org/jesi/ 2020 Volume 8 Number 2 (December)

http://doi.org/10.9770/jesi.2020.8.2(70)

Make your research more visible, join the Twitter account of ENTREPRENEURSHIP AND SUSTAINABILITY ISSUES:@Entrepr69728810

Table 1. Structure of gross value added by industry in Kazakhstan (in \%)

\begin{tabular}{|c|c|c|c|c|c|c|c|}
\hline Industries & 2013 & 2014 & 2015 & 2016 & 2017 & 2018 & 2019 \\
\hline Total & 35999,0 & 39675,8 & 40884,1 & 46971,2 & 53101,3 & 60004,5 & 67805,0 \\
\hline $\begin{array}{l}\text { Agriculture, } \\
\text { forestry and } \\
\text { fisheries, in billion } \\
\text { tenge }\end{array}$ & 1621,2 & 1717,8 & 1925,9 & 2140,0 & 2315,2 & 2700,0 & 2915,6 \\
\hline$\%$ & 4,5 & 4,3 & 4,7 & 4,6 & 4,4 & 4,5 & 4,3 \\
\hline $\begin{array}{l}\text { Industry, in billion } \\
\text { tenge }\end{array}$ & 9986,0 & 10818,1 & 10167,0 & 12262,5 & 14213,4 & 15601,1 & 17687,1 \\
\hline$\%$ & 27,7 & 27,3 & 24,9 & 26,1 & 26,8 & 26,0 & 26,1 \\
\hline $\begin{array}{l}\text { Construction, in } \\
\text { billion tenge }\end{array}$ & 2145,3 & 2358,0 & 2447,7 & 2758,8 & 2896,7 & 3360,3 & 3729,3 \\
\hline$\%$ & 6,0 & 5,9 & 6,0 & 5,9 & 5,5 & 5,6 & 5,5 \\
\hline $\begin{array}{l}\text { Wholesale and retail } \\
\text { trade; repair of cars } \\
\text { and motorcycles, in } \\
\text { billion tenge }\end{array}$ & 5416,0 & 6332,7 & 6994,0 & 7898,8 & 8440,6 & 9600,7 & 10916,7 \\
\hline$\%$ & 15,0 & 16,0 & 17,1 & 16,8 & 15,9 & 16,0 & 16,1 \\
\hline
\end{tabular}

Source: compiled by authors according to the source Committee on Statistics of the Ministry of National Economy of the Republic of Kazakhstan

Investments in fixed assets in the extractive industry today account for more than $30 \%$ of the total, and in the manufacturing industry only 12\% (Committee on Statistics of the Ministry of National Economy of the Republic of Kazakhstan). Kazakhstan, which is a leading exporter of extractive industry products (primarily due to the export of extracted oil), is ahead of all CIS countries in terms of per capita export. However, the average per capita export of manufacturing products in the Republic of Kazakhstan is relatively low - approximately two times lower than in Russia.At the end of 2019, compared to 2014, Kazakhstan shows a positive growth trend in terms of the main indicators: GDP grew by $75.3 \%$, including industry - by $58.6 \%$, construction - by $66.2 \%$, agriculture, forestry and fisheries - by $63.9 \%$, the volume of innovative products -2.0 times, the energy intensity of GDP decreased by $13.6 \%$ (Table 2 ).

Table 2. Dynamics of the main indicators by the main target indicators for 2014-2019

\begin{tabular}{|l|c|c|c|c|c|c|}
\hline Indicator & 2014 & 2015 & 2016 & 2017 & 2018 & 2019 \\
\hline Industry, in million tenge & 18529225 & 14903099 & 19026781 & 22790209 & 27218063 & 29380342 \\
\hline Construction, in million tenge & 2667183 & 2896877 & 3258031 & 3509296 & 3862995 & 4431666 \\
\hline Agriculture, forestry and fisheries, in billion tenge & 3143678,1 & 3307009,6 & 3684393,2 & 4070916,8 & 4474088,1 & 5151163,0 \\
\hline $\begin{array}{l}\text { Share of innovative products (goods, services) to } \\
\text { GDP, in \% }\end{array}$ & 1,46 & 0,92 & 0,95 & 1,59 & 1,98 & 1,89 \\
\hline $\begin{array}{l}\text { Share of innovative products (goods, services) of } \\
\text { industrial enterprises in the total volume of } \\
\text { industrial production, in \% }\end{array}$ & 2,61 & 1,80 & 1,81 & 3,18 & 3,77 & 3,56 \\
\hline $\begin{array}{l}\text { Share of innovatively active enterprises from the } \\
\text { number of operating, }\end{array}$ & 4,0 & 4,0 & 4,3 & 7,1 & 7,6 & 7,3 \\
\hline Volume of innovative products, in billion tenge & 580,4 & 377,2 & 445,8 & 844,7 & 1179,2 & 1235,3 \\
\hline
\end{tabular}

Source: compiled by authors according to the source Committee on Statistics of the Ministry of National Economy of the Republic of Kazakhstan 
Make your research more visible, join the Twitter account of ENTREPRENEURSHIP AND SUSTAINABILITY ISSUES:@Entrepr69728810

Economy of the Republic of Kazakhstan is one of the fastest growing in the CIS. The observed growth was largely due to large foreign investors in the oil and gas industry, the expansion of which had a positive impact on other industries. However, economic growth is still largely dependent on the growth of oil and gas production in Kazakhstan, as well as the global market conditions for these products (Official site of JSC "National Managing Holding "Baiterek").

Kazakhstan ranks roughly 50th in the list of countries in terms of nominal gross domestic product. In 2018, the GDP of Kazakhstan amounted to 61.8 trillion tenge (3.4 million tenge per capita, or 9812.5 US dollars). For 9 months of 2019, the GDP of Kazakhstan amounted to 44.3 trillion tenge. The estimate of Kazakhstan's GDP for the full year of 2019 is 67.7 trillion tenge (Committee on Statistics of the Ministry of National Economy of the Republic of Kazakhstan).

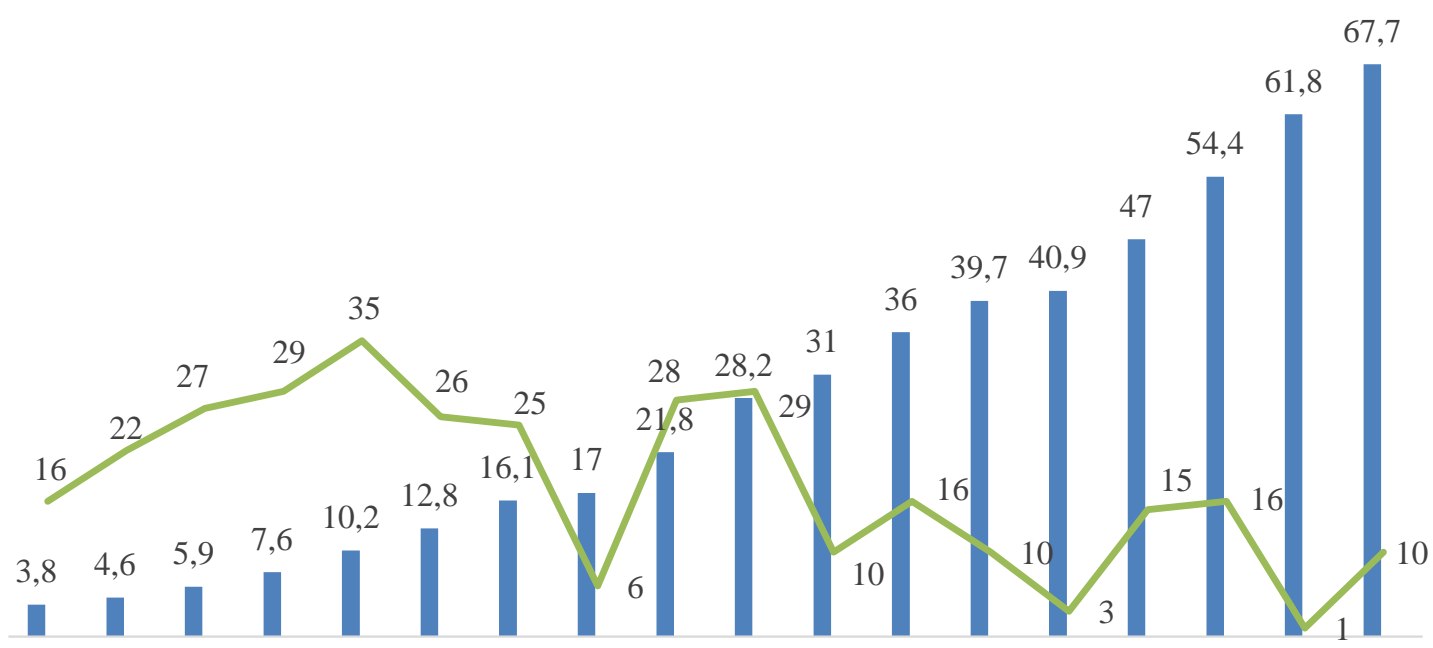

200220032004200520062007200820092010201120122013201420152016201720182019

GDP, in trillion $\quad$ Variation, in $\%$

Figure 2. Analysis of GDP dynamics in Kazakhstan for the period from 2002-2019

Source: compiled by authors according to the source Committee on Statistics of the Ministry of National Economy of the Republic of Kazakhstan

In connection with the raw materials orientation and export orientation of the economy of Kazakhstan, its development is closely related to the situation in the market of raw materials, primarily oil and metals.From 2000 to 2011, Kazakhstan's GDP showed rapid real growth at double-digit levels with short-term adjustments in 20082009 due to the impact of the global financial crisis. From 2012 to 2014, the country's growth rates have stabilized at the level of 4-6\%. Such dynamics of growth rates is explained by the significant consolidation of the country's economy against the background of high prices for oil and metals. In 2015-2016 there was a drop in GDP growth to 1.2 and $1.1 \%$, respectively, as a consequence of the collapse in oil prices. At the same time, since 2017, there has been a recovery in economic growth indicators in Kazakhstan - slightly above 4\% (Figure 2).

At present, industrial production in the structure of Kazakhstan's GDP is 44\%. The volume of industrial production in monetary terms amounted to 27.2 trillion tenge. In the structure of industrial production, the leading positions are occupied by the mining and manufacturing industries - 54\% and 38\%, respectively (Figure 3 ). 


\section{ENTREPRENEURSHIP AND SUSTAINABILITY ISSUES}

ISSN 2345-0282 (online) http://jssidoi.org/jesi/

2020 Volume 8 Number 2 (December)

http://doi.org/10.9770/jesi.2020.8.2(70)

Make your research more visible, join the Twitter account of ENTREPRENEURSHIP AND SUSTAINABILITY ISSUES:@Entrepr69728810

Industrial production volumes since 2000 to 2015 increased annually by an average of $20 \%$, but in 2015 there was a sharp decrease of $21 \%$ in relation to 2014 .

The main reasons for the decline were the following factors:

- production volumes in the mining industry decreased by $33 \%$;

- in the manufacturing industry decreased by $6 \%$;

- in the field of electricity, gas, steam and air conditioning, production increased by $4 \%$;

- in the sector of water supply, sewerage system, control over the collection and distribution of waste, production increased by $3 \%$.

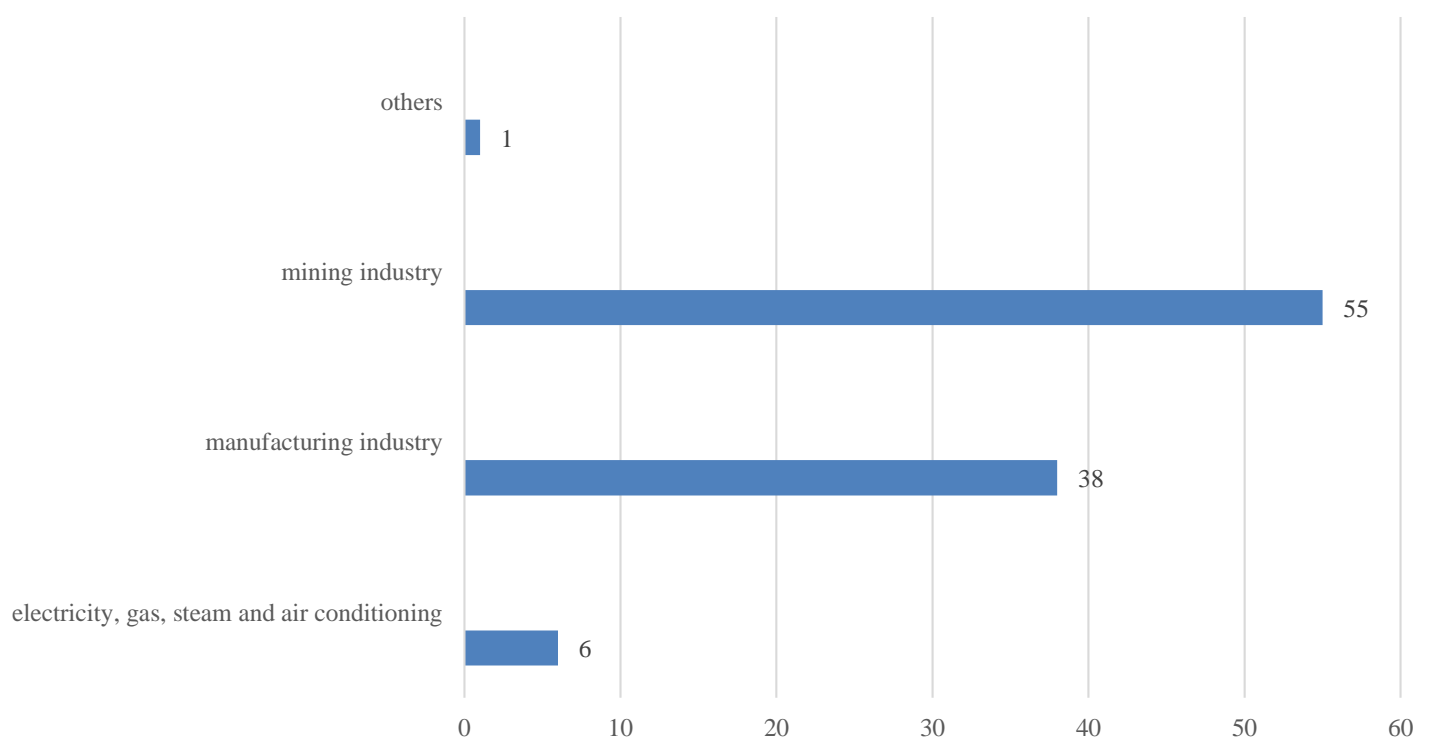

Figure 3. Structure of industrial production in Kazakhstan, in \%

Source: compiled by authors according to the source Committee on Statistics of the Ministry of National Economy of the Republic of Kazakhstan

Since 2016 the volume of industrial production began to recover due to the increase in production volumes in all sectors. Thus, the average annual growth since 2016 is $22 \%$. Business susceptibility to technological innovation remains low, but is growing moderately. In 2019, the share of innovatively active enterprises amounted to $7.3 \%$ of the total number of industrial enterprises, which is significantly lower than the values typical for Germany (73\%), Ireland (61\%), Belgium (58\%), Czech Republic (41\%) (Official site of Eurostat, 2019.). Qualitatively, the insufficient level of innovative activity is aggravated by the low return on the implementation of technological innovations. The expenditures of Kazakhstan companies on R\&D (in \% of GDP) remain extremely low $0.3 \%$ of GDP, which is even lower than the indicators of Russia 1.4\%, Ukraine $0.9 \%$ and Belarus $0.7 \%$ (Official site of Eurostat, 2019). In addition to the "quantitative" lag of Kazakhstan companies in terms of innovation activity, there are significant structural problems in organizing innovation management at the company level.

The share of products of Kazakhstan companies in the global export of high-tech civilian products is zero. The reasons for the persistently weak positions of Kazakhstan companies are the lack of high-quality scientific research close to production and weak competencies and visions at the level of company leaders, who save on development, postponing innovative projects and $\mathrm{R} \& \mathrm{D}$ costs for an indefinite future. 


\section{ENTREPRENEURSHIP AND SUSTAINABILITY ISSUES}

ISSN 2345-0282 (online) http://jssidoi.org/jesi/

2020 Volume 8 Number 2 (December)

http://doi.org/10.9770/jesi.2020.8.2(70)

Make your research more visible, join the Twitter account of ENTREPRENEURSHIP AND SUSTAINABILITY ISSUES:@Entrepr69728810

In Kazakhstan, the dependence of the state budget on revenues from oil exports continues to grow. Oil revenues account for more than $50 \%$ of the consolidated revenues of the state, and the budget deficit, excluding these revenues, reaches $9.3 \%$ of GDP. The transfer of the National Fund of the Republic of Kazakhstan provides financing for almost a fifth of all government spending.

Kazakhstan has come close to the problem of the "middle income trap". Upon reaching a certain level of wellbeing in the range from 10 thousand to 15 thousand US dollars of GDP per capita, the growth of the economy of the Republic of Kazakhstan may slow down. The economy may lose competitiveness and turn out to be a country with a low level of income. As the global experience of economic development shows, few countries manage to overcome the threshold of middle income: of more than 100 countries that quickly reached middle income half a century ago, only about a dozen have managed to become high-income countries. The main strategy for breaking through the "trap" is the accelerated development of industry, including manufacturing.

Thus, starting from 2010 to the present, the foundations of modern industrial policy in the Republic of Kazakhstan were laid. The main regulatory legal acts were adopted; various instruments for supporting industrial development and new policy directions were tested. In particular, mechanisms were launched to attract foreign direct investment and support exports, and the process of transforming special economic zones was launched. Diversification of the economy has begun through the accelerated development of the manufacturing industry, an increase in non-resource exports and the attraction of foreign direct investment in non-resource sectors. The production of more than 150 new types of products has been mastered. These are high-tech products of mechanical engineering, pharmaceuticals and chemical industries.

In modern conditions, when entrepreneurial activity is aimed at improving management mechanisms, at creating competitive advantages, it is necessary to analyze the activities of companies to identify hidden reserves and prevent possible financial threats. In a market economy, there is an objective need to identify trends in the development of the financial condition and prospective financial capabilities of the enterprise.

In this regard, the monitoring of the financial condition is carried out, which is aimed at assessing the condition of the objects under study in conditions of insufficient information in order to identify problems in the functioning of systems and the causes of their occurrence, where the assessment of the company's performance is an important part of the analysis of the company's financial condition within the framework of monitoring. In this regard, let us consider the main indicators of the financial and economic activity of industrial enterprises in 2013-2018 (Table 3).

Table 3. Main indicators of financial and economic activity of industrial enterprises in 2013-2018 (in mln. tenge)

\begin{tabular}{|c|c|c|c|c|c|c|}
\hline Indicators & 2013 & 2014 & 2015 & 2016 & 2017 & 2018 \\
\hline \multicolumn{7}{|c|}{ Profit (loss) before taxes } \\
\hline Mining and quarrying & & & & & & \\
\hline & 3587590 & 3896193 & 1255610 & 2369873 & 3819446 & 6295007 \\
\hline $\begin{array}{l}\text { Manufacturing } \\
\text { industry }\end{array}$ & 379103 & 315367 & -382511 & 1163171 & 1325462 & 1219902 \\
\hline \multicolumn{7}{|c|}{ Income from the sale of products and the provision of services } \\
\hline Mining and quarrying & & & & & & \\
\hline & 9684522 & 10094638 & 6857698 & 8608846 & 10305442 & 13317567 \\
\hline
\end{tabular}




\section{ENTREPRENEURSHIP AND SUSTAINABILITY ISSUES}

ISSN 2345-0282 (online) http://jssidoi.org/jesi/

2020 Volume 8 Number 2 (December)

http://doi.org/10.9770/jesi.2020.8.2(70)

Make your research more visible, join the Twitter account of ENTREPRENEURSHIP AND SUSTAINABILITY ISSUES:@Entrepr69728810

\begin{tabular}{|c|c|c|c|c|c|c|}
\hline $\begin{array}{l}\text { Manufacturing } \\
\text { industry }\end{array}$ & 4891974 & 4932510 & 4461696 & 6358983 & 7486506 & 8446819 \\
\hline \multicolumn{7}{|c|}{ Cost of goods sold and services rendered } \\
\hline \multicolumn{7}{|c|}{ Mining and quarrying } \\
\hline & 3729112 & 4038598 & 3327398 & 4198140 & 4405439 & 5268474 \\
\hline $\begin{array}{l}\text { Manufacturing } \\
\text { industry }\end{array}$ & 3822736 & 3653639 & 3275786 & 4346626 & 5016486 & 5636716 \\
\hline \multicolumn{7}{|c|}{ Debt on obligations } \\
\hline \multicolumn{7}{|c|}{ Mining and quarrying } \\
\hline & 3977449 & 4306648 & 6684909 & 8737147 & 8325743 & 9375074 \\
\hline $\begin{array}{l}\text { Manufacturing } \\
\text { industry }\end{array}$ & 3537717 & 4585871 & 6348099 & 7520655 & 7962131 & 8455645 \\
\hline \multicolumn{7}{|c|}{ Receivables } \\
\hline Mining and que & & & & & & \\
\hline & 1385864 & 1270446 & 1439869 & 1325902 & 1458080 & 1476967 \\
\hline $\begin{array}{l}\text { Manufacturing } \\
\text { industry }\end{array}$ & 1234013 & 1232638 & 1304282 & 1938003 & 2184200 & 2249550 \\
\hline
\end{tabular}

Based on Table 3, it can be seen that the main share in all indicators is occupied by the mining industry and quarrying, so the income from product sales in 2018 compared to 2013 increased by $37.5 \%$ due to an increase in the average selling price and amounted to 13317.6 billion tenge. In the manufacturing industry, income grew by $72.7 \%$, reaching $8,446.9$ billion tenge.

\section{Application functionality}

With the help of regression analysis, we will analyze the influence of the presented indicators of financial and economic activity of the mining industry and the development of quarries and the manufacturing industry on their profit. As a result of the analysis of the main indicators of financial and economic activity of industrial enterprises of the Republic of Kazakhstan, it was revealed that the main share in all indicators is occupied by the mining industry, quarrying and manufacturing. Therefore, for further comparative analysis of the two industries under consideration, authors set the task to show the difference between the formation of pre-tax profit by increasing income, which is necessary for more efficient cost management in the studied industries. For this, regression analysis was used using the least squares method, which made it possible to analyze the impact of the presented indicators of financial and economic activity in the mining industry, development of quarries and the manufacturing industry on their profit.

As explanatory factors, income from sales of products and debt on liabilities were selected, which, as a result of comparing the two industries under consideration, showed a significant difference between the formation of pretax profit by increasing income. The analysis of the monitoring showed that more efficient cost management is carried out in the mining and quarrying industries compared to the manufacturing industry. This indicates that monitoring the innovative potential of industrial enterprises and their innovative activity is of particular importance for the future development of the industry. In this regard, the monitoring of the financial condition is carried out, 


\section{ENTREPRENEURSHIP AND SUSTAINABILITY ISSUES}

ISSN 2345-0282 (online) http://jssidoi.org/jesi/

2020 Volume 8 Number 2 (December)

http://doi.org/10.9770/jesi.2020.8.2(70)

Make your research more visible, join the Twitter account of ENTREPRENEURSHIP AND SUSTAINABILITY ISSUES:@Entrepr69728810

which is aimed at assessing the condition of the objects under study in conditions of insufficient information in order to identify problems in the functioning of systems and the causes of their occurrence, where the assessment of the company's performance is an important part of the analysis of the company's financial condition within the framework of monitoring. Based on the analysis of the financial results of industrial enterprises, their business and market activity, it follows that the main attention of the financial management of enterprises should be paid to increasing the operating and net profit of the company, and due to this, the indicators of the company's profitability. As a result, authors formulated conclusions and recommendations for improving monitoring of the activities of industrial enterprises of the Republic of Kazakhstan, since the importance of monitoring affects the high rating of enterprises, allows them to have financial and economic advantages in the market of credit resources and investment funds, to receive promising government orders, to consistently increase the value of the enterprises themselves and their securities.

For this, the following hypotheses were formulated:

1. Analyzing the impact of indicators of financial and economic activities (income from sales of products and debt on obligations) of the mining and manufacturing industries on their profits.

2. Based on the analysis of the financial condition of industrial enterprises, predicting the indicators of production volumes and profitability of industrial enterprises, namely:

- forecast of the volume of investments in fixed assets of the industry;

- forecast of profitability;

- forecast of the amount of profit (loss) before tax.

3. Formulating conclusions and recommendations for improving monitoring of the activities of industrial enterprises of the Republic of Kazakhstan, which affects the financial and economic advantages in the market of credit and financial resources.

After assessing the statistical significance of the variables, income from sales of products and debt on obligations were chosen as explanatory factors. To build an econometric model, the statistical data of these indicators were used for the period from 2013 to 2018. The results of the regression analysis carried out using the least squares method are shown below (Table 4).

Table 4. Results of evaluating the pre-tax profit equation for mining and quarrying

\begin{tabular}{|l|l|}
\hline$R$ & 0,999 \\
\hline$R^{2}$ & 0,998 \\
\hline Adjusted $R^{2}$ & 0,997 \\
\hline The observed value of the Fisher test & 940,915 \\
\hline Critical Fisher's criterion & $9,552\left(\alpha=0,05, k_{1}=2, \quad k_{2}=3\right)$ \\
\hline Variables & Regression coefficients \\
\hline Profit before tax (million tenge) - dependent variable \\
\hline Constant & $-4016044,104 * * *$ \\
\hline \multicolumn{2}{|l|}{ Sncome from the sale of products and the } \\
provision of services
\end{tabular} \mid \begin{tabular}{l}
\hline \\
\hline Debt on obligations
\end{tabular}

The multiple correlation coefficients indicate a close relationship of the resulting trait with two factorial traits at the same time, and the corrected determination coefficient indicates that $99.7 \%$ of the variation in the dependent 


\section{ENTREPRENEURSHIP AND SUSTAINABILITY ISSUES}

ISSN 2345-0282 (online) http://jssidoi.org/jesi/

2020 Volume 8 Number 2 (December)

http://doi.org/10.9770/jesi.2020.8.2(70)

Make your research more visible, join the Twitter account of ENTREPRENEURSHIP AND SUSTAINABILITY ISSUES:@Entrepr69728810

variable is explained by the resulting regression. The equation as a whole, as well as its individual parameters, is statistically significant and reliable with a $95 \%$ probability.

The analysis of the obtained parameters of the multiple linear regression equation allows us to draw the following conclusions for mining and quarrying enterprises:

1) with an increase in income from the sale of products and the provision of services by 1 million tenge, profit before tax increases on average by 0.810 million tenge;

2) with an increase in debt on liabilities by 1 million tenge, profit before tax decreases on average by 0.057 million tenge (Table 5).

Table 5. The results of evaluating the equation of profit before tax for the manufacturing industry

\begin{tabular}{|l|l|}
\hline$R$ & 0,894 \\
\hline$R^{2}$ & 0,799 \\
\hline Adjusted $R^{2}$ & 0,664 \\
\hline The observed value of the Fisher test & 5,950 \\
\hline Critical Fisher's criterion & $5,462\left(\alpha=0,1, k_{1}=2, \quad k_{2}=3\right)$ \\
\hline Variables & $-1559717,961^{*}$ \\
\hline Profit before tax (million tenge) - dependent variable \\
\hline Constant & Regression coefficients \\
\hline \multicolumn{2}{|l|}{ Source: compiled and calculated by authors } \\
\hline provision of services
\end{tabular}

The multiple correlation coefficients indicate a close relationship between the resulting trait and two factorial traits at the same time, and the corrected determination coefficient indicates that $66.4 \%$ of the variation in the dependent variable is explained by the resulting regression. The equation as a whole, as well as its individual parameters, is statistically significant and reliable with a $90 \%$ probability. The resulting multiple linear regression equation allows us to draw the following conclusions for manufacturing enterprises:

1) with an increase in income from the sale of products and the provision of services by 1 million tenge, profit before tax increases on average by 0.455 million tenge;

2) with an increase in debt on liabilities by 1 million tenge, profit before tax decreases by an average of 0.085 million tenge.

Thus, a comparison of the two industries under consideration showed a significant difference between the formations of pre-tax profit by increasing income. So, with an increase in income by 1 million tenge, profit in the mining industry and quarrying increases by an average of 810 thousand tenge, while in the manufacturing industry by only 455 thousand tenge. This may indicate more efficient cost management in the mining and quarrying industries compared to the manufacturing industry.

Trade and other receivables from related parties represent primarily amounts related to export sales. Trade receivables from manufacturing enterprises amounted to 2,184 billion tenge in 2017 and 2,249.6 billion tenge in 2018, with an increase of almost 2 times. In the mining and quarrying industries, there is also an increase of $6.6 \%$ or for $91 \mathrm{bn}$. tenge. The size of the companies' liabilities also doubled in 2018 compared to 2013, reaching the level in the mining industry of 9,375.1 billion tenge and processing 8,455.6 billion tenge. Based on the analysis of the 


\section{ENTREPRENEURSHIP AND SUSTAINABILITY ISSUES}

ISSN 2345-0282 (online) http://jssidoi.org/jesi/

2020 Volume 8 Number 2 (December)

http://doi.org/10.9770/jesi.2020.8.2(70)

Make your research more visible, join the Twitter account of ENTREPRENEURSHIP AND SUSTAINABILITY ISSUES:@Entrepr69728810

financial results of the studied company, its business and market activity, it follows that the main attention of the financial management of the company should be paid to increasing the operating and net profit of the company, and due to this, the indicators of the company's profitability.

The main growth factors for these indicators are:

- increase in production, decrease in production;

- operating costs of the company;

- management of the turnover of current assets.

The analysis of the financial condition of industrial enterprises allows us to move on to the next stage of monitoring the financial condition of the company, forecasting the main parameters of the company. When forecasting, longterm plans for the development of the company are developed and indicators are calculated, on the basis of which it is possible to assess the financial condition of the company or individual aspects of its financial and economic activities. The starting point for developing a long-term plan of income and expenses is the forecast of volume sales in kind and in value terms. The main tool for any forecast is the extrapolation scheme. The essence of extrapolation is to study the stable trends in the development of the forecast object that have developed in the past and the present and carry them over to the future. Extrapolation methods are the most widespread and well-developed. The basis of extrapolation forecasting methods is the study of time series. A time series is a set of observations obtained sequentially in time. Let us illustrate the use of this method by the example of forecasting the profitability and the indicator of the volume of industrial production in the Republic of Kazakhstan. To carry out the calculations, we will use the time series data for the period 2013-2018, presented in Table 6.

Table 6. Forecast of the volume of production and profitability of industrial enterprises, $\%$

\begin{tabular}{|c|c|c|c|c|c|}
\hline $\begin{array}{c}\text { period } \\
\text { number }\end{array}$ & Years & $\begin{array}{c}\text { Forecast of the } \\
\text { volume of industrial } \\
\text { production, in } \\
\text { million tenge }\end{array}$ & $\begin{array}{c}\text { Forecast of the } \\
\text { volume of } \\
\text { investments in fixed } \\
\text { assets of the } \\
\text { industry, in million } \\
\text { tenge }\end{array}$ & $\begin{array}{c}\text { Profitability } \\
\text { forecast, in \% } \\
\text { amount of profit } \\
\text { (loss) before tax, in } \\
\text { million tenge }\end{array}$ \\
\hline $\mathrm{x}$ & & $\mathrm{f}(\mathrm{x})$ & $\mathrm{f}(\mathrm{x})$ & $\mathrm{f}(\mathrm{x})$ & $\mathrm{f}(\mathrm{x})$ \\
\hline 1 & 2013 & 17833994 & 3069814 & 17 & 5104019 \\
\hline 2 & 2014 & 18529225 & 3508871 & -10 & 5100655 \\
\hline 3 & 2015 & 14931378 & 3863090 & 18 & -1856075 \\
\hline 4 & 2016 & 19026781 & 4320396 & 24,3 & 5931748 \\
\hline 5 & 2017 & 22790209 & 4769589 & 23,0 & 3190133 \\
\hline 6 & 2018 & 21745313,200 & 5169674,500 & 22,053 & 8819060 \\
\hline 7 & 2019 forecast & 22786311,800 & 5590782,000 & 28,769 & 9730672 \\
\hline 8 & 2020 forecast & 24517269,760 & 6014917,233 & 38,184 & 10396086,401 \\
\hline 9 & 2021 forecast & 26782526,000 & 6451779,422 & 37,122 & 13863921,288 \\
\hline 10 & 2022 forecast & 27441492,381 & 6867590,624 & 70,543 & 14874303,865 \\
\hline 11 & 2023 forecast & 28353755,017 & 7286767,942 & 17567781,351 \\
\hline
\end{tabular}

Source: compiled and calculated by authors

We will smooth the time series using one of the main methods of regression analysis - the least squares method. As a result, we obtain a linear trend dependence of the form (Figure 4, 5, 6): 
Make your research more visible, join the Twitter account of ENTREPRENEURSHIP AND SUSTAINABILITY ISSUES:@Entrepr69728810

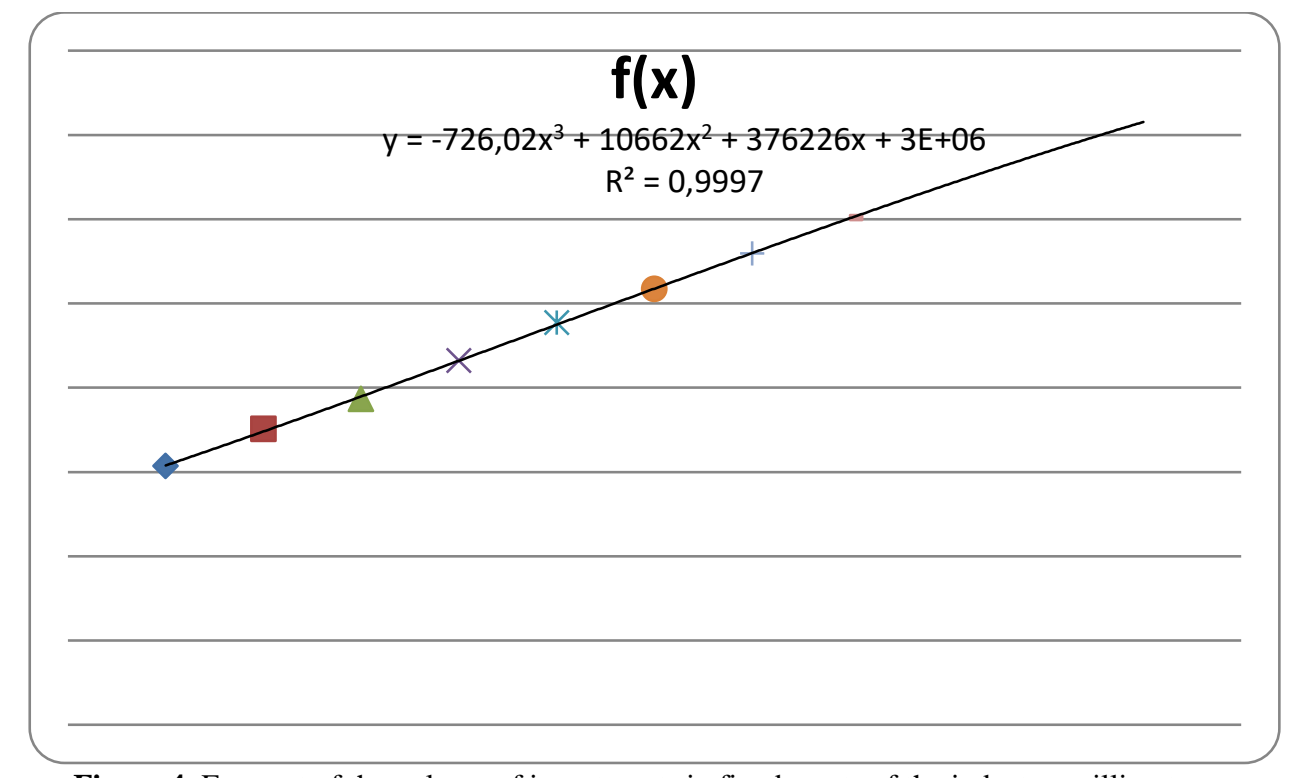

Figure 4. Forecast of the volume of investments in fixed assets of the industry, million tenge Source: compiled and calculated by authors

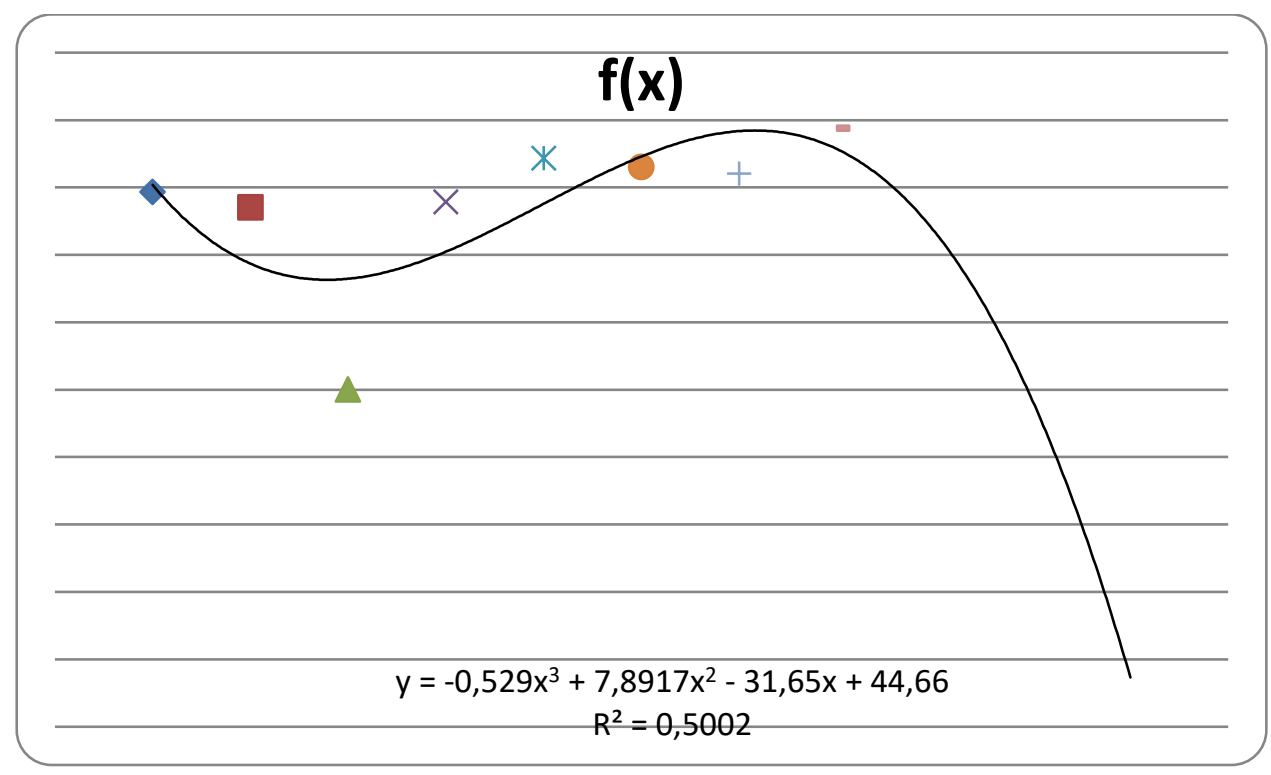

Figure 5. Forecast of profitability, in \% Source: compiled and calculated by authors

The forecast data show that the profitability of the industry by 2023 will grow to $40.5 \%$. The growth will occur mainly due to the extensive factor - the growth in the volume of investments in fixed assets of the industry, which over the same period will grow almost 2.5 times. 
Make your research more visible, join the Twitter account of ENTREPRENEURSHIP AND SUSTAINABILITY ISSUES:@Entrepr69728810

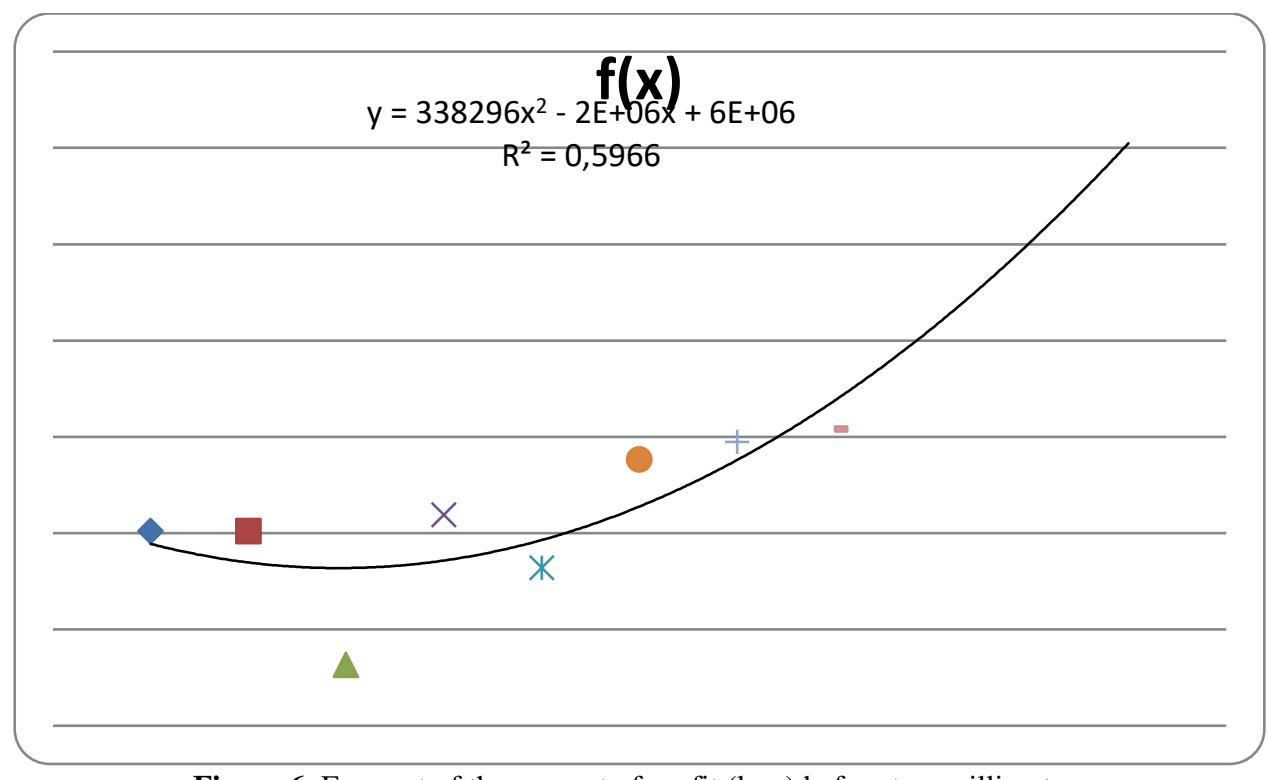

Figure 6. Forecast of the amount of profit (loss) before tax, million tenge Source: compiled and calculated by authors

For a more complete diagnosis, timely identification of crisis situations in the economy, external state monitoring of the financial condition of enterprises is required (Savitskaya, 2013). At present, the state exercises only control over the bankruptcy procedure of insolvent enterprises (Govorova, 2016).

In modern conditions, the problem of financial insolvency of enterprises is very relevant, therefore, it is necessary to introduce assessment systems for these enterprises, which could serve as indicators of the success of their activities, reflect the degree of attractiveness for investors, and be an internal incentive for the development of enterprises themselves.

In this connection, the main functions of monitoring the financial condition of the company should be:

- analytical function, which assumes, on the basis of constant monitoring of the object, the analysis of its financial condition, which includes the measurement of real results and their correlation with the set goals, standards, and norms;

- diagnostic, implying the interpretation of the results obtained and allowing an objective assessment of the results of the analysis of the monitoring object;

- function of forecasting, is to develop long-term changes in the financial condition of the company;

- organizational and managerial, involving control over the state of the monitoring object and preparation of recommendations for making corrective and proactive managerial decisions.

In terms of profitability indicators, the most indicative is the ratio of the amount of net profit to own capital, since it shows how effectively the shareholder capital invested in the enterprise is being used. Also the most important is the rate of return on assets (resource productivity), which characterizes the intensity of the use of the company's assets for the production of products.

To monitor the financial condition of strategic enterprises at the state level, the following system of indicators is proposed:

- degree of solvency for current obligations;

- current liquidity ratio;

- ratio of debt and equity funds;

- ratio of provision with own funds; 


\section{ENTREPRENEURSHIP AND SUSTAINABILITY ISSUES}

ISSN 2345-0282 (online) http://jssidoi.org/jesi/

2020 Volume 8 Number 2 (December)

http://doi.org/10.9770/jesi.2020.8.2(70)

Make your research more visible, join the Twitter account of ENTREPRENEURSHIP AND SUSTAINABILITY ISSUES:@Entrepr69728810

- ratio of stocks provision with own circulating assets;

- return on assets;

- return on equity.

In order to identify problems in the functioning of systems and the reasons for their occurrence, the need to monitor the financial condition of enterprises is obvious. The analysis carried out and the results obtained showed that the main focus of the financial management of enterprises should be aimed at increasing the operating and net profit of the company.

On the basis of forecasting indicators of production volumes and profitability of industrial enterprises, authors formulated conclusions and recommendations for improving monitoring of the activities of industrial enterprises of the Republic of Kazakhstan, contributing to the creation of conditions for balanced, environmentally-oriented growth, understanding the factors contributing to economic development, with due regard for the problems of sustainability, economic and social well-being.

The obtained results of the study indicate that monitoring the innovative potential of industrial enterprises and their innovative activity is of particular importance for the future development of the industry.

The proposed system of indicators for monitoring the financial condition of strategic companies, should be carried out at the state level, will reduce the risk of insolvency, bankruptcy of these companies, and most importantly, the risk of negative impact of the deterioration in the financial condition of strategic companies on the country's economy as a whole. In this regard, monitoring the financial condition of strategic companies will facilitate the timely detection of signs of significant deviations from normal economic development and, thereby, provide a real opportunity for the government and company management to take measures to prevent crisis situations.

\section{Conclusion}

When monitoring industrial enterprises, a large number of various economic and financial indicators are analyzed, some of which are available and determine the activities of companies and the industry as a whole. Access to other indicators requires the maximum transparency of enterprise management.

An analysis of the set of indicators used, which are compiled on the basis of a limited set of formal indicators, cannot give a complete picture of the situation of an enterprise. There are also a number of criteria that are difficult or even impossible to capture using quantitative indicators. These informal criteria can significantly affect the assessment of the effectiveness of enterprise management.

At present, the existing monitoring theory does not fully and adequately reflect the features of its development at the present stage, including its role in the process of managing the enterprise's activities. The results of the study, presented in this article, indicate the existence of feedback, information, instrumental and organizational support in the monitoring system. It should also be noted the implementation of its coordinating and integrating functions, which are implemented in the management process. The need to integrate management functions is due to the requirement for their operational adaptation, as well as ensuring the effective functioning of industrial enterprises in modern dynamic conditions.

We would also note that in the context of digital transformation, the way to control the processes at the enterprise is changing. The interaction of IT and business is becoming closer - it is necessary to control technological and business processes at the same time. Universal monitoring systems organize a single point for collecting data of various types from various sources and notify about events that must support:

- multifunctionality - access to monitoring a wide range of parameters;

- integration - support for many protocols and technologies for data collection; 


\section{ENTREPRENEURSHIP AND SUSTAINABILITY ISSUES}

ISSN 2345-0282 (online) http://jssidoi.org/jesi/

2020 Volume 8 Number 2 (December)

http://doi.org/10.9770/jesi.2020.8.2(70)

Make your research more visible, join the Twitter account of ENTREPRENEURSHIP AND SUSTAINABILITY ISSUES:@Entrepr69728810

- availability;

- reporting - flexible reporting system with different levels of detail;

- notifications - configure the delivery methods for event notifications.

Thus, the monitoring system of industrial enterprises is the interaction of accounting, planning, control, regulation and analysis processes, taking into account the priority areas and development goals of the enterprise, through instrumental, methodological, organizational and information support.

\section{References}

Abeldanova, A., Smailova, Z. 2017. Modeling the Functional System of Small Business Development in the Republic of Kazakhstan. Journal of Advanced Research in Law and Economics, 6(28), 1671 - 1678.https://doi.org/10.14505/jarle

Akanova, K. 2015. Economic and mathematical models and methods. Almaty: LEM, 142 p.

Akulov, V., Rudakov, M. 2015. Peculiarities of decision-making by the subject of strategic management. Problems of theory and law of management, 5(12), 547-556.

Babaytsev, A., Kuznetsova, E., Rabinskiy, L., Tushavina, O. 2020. Investigation of permanent strains in nanomodified composites after molding at elevated temperatures. PeriodicoTcheQuimica, 17(34), 1055-1067.https://www.periodico.tchequimica.com

Barikayev, E. 2015. Business risk management in the economic security system. Theoretical aspect: Monograph. Moscow: UNITI, 159 p.

Batkovskiy, M.,Kravchuk, P. 2019. Creating a system of monitoring the activity of innovative-active enterprises. Creative Economy, 13(1), 78-96. https://doi.org/10.18334/ce.13.1.39738.

Berstembayeva, R., Tleuzhanova, D. 2017. Financial Aspects of Integration in the Conditions of Formation of the Eurasian Economic Union. Entrepreneurial Environment in the Current Financial Politics of Kazakhstan. Journal of Advanced Research in Law and Economics, 4(26), 1088 - 1094.https://doi.org/10.14505/jarle

Berdar, M. 2020. Formulation of enterprise marketing strategy in the context of internationalization of markets. Asia Life Sciences, 2(22), 497-510.

Bogatenkov, S., Belevitin, V., Khasanova, M. 2018. Risk Management Based on Model of Competences when Introducing Innovative Information Technology. International Journal of Engineering \& Technology, 7(38), 78-81. https://www.researchgate.net/deref/http\%3A\%2F\%2Fwww.sciencepubco.com\%2Findex.php\%2FIJET

Branichev, V. 2018. Strategic analysis of management. Moscow: UNITI, 57 p.

Chowdhury, P., \& Paul Sanjoy, K. (2020). Applications of MCDM methods in research on corporate sustainability: A systematic literature review. Management of Environmental Quality: An International Journal, 31(2), 385-405.

https://www.emerald.com/insight/content/doi/10.1108/MEQ-12-2019-0284/full/html

Cuevas-Vargas, H., Parga-Montoya, N., Fernández-Escobedo, R. 2016. Effects of Entrepreneurial Orientation on Business Performance: The Mediating Role of Customer Satisfaction. A Formative-Reflective Model Analysis. Journals Sage, 45(77), 440-458. https://doi.org/10.1177/2158244019859088

Dzhamay, E. 2017. Enterprise Finance: Essence, Composition and Structure. International journal of applied business and economic research, 15(23), 297-304. https://www.researchgate.net/publication/323186409_Enterprise_finance_Essence_composition_and_structure 


\section{ENTREPRENEURSHIP AND SUSTAINABILITY ISSUES}

ISSN 2345-0282 (online) http://jssidoi.org/jesi/

2020 Volume 8 Number 2 (December)

http://doi.org/10.9770/jesi.2020.8.2(70)

Make your research more visible, join the Twitter account of ENTREPRENEURSHIP AND SUSTAINABILITY ISSUES:@Entrepr69728810

Govorova, N. 2016. Competitiveness is the main factor in the development of the modern economy. Problems of theory and practice of management, 4(11), 25-37.

Gruzinov, V., Gribov, V. 2015. Enterprise Economics. Moscow: Finance and Statistics, 584 p.

Grynko, T., Krupskyi, O. 2017. Optimization of the Financial and Budgetary Mechanism for the Functioning of Educational Institutions of Higher Education in the Conditions of Innovative Economy Development in the Russian Federation. Entrepreneurial Environment in the Current Financial Politics of Kazakhstan. Journal of Advanced Research in Law and Economics, 4(26), 1100-1113. https://doi.org/10.14505/jarle

Hilkevics, S., Semakina, V. 2019. The classification and comparison of business ratios analysis methods. Insights into Regional Development 1(1), 48-57. https://doi.org/10.9770/ird.2019.1.1(4)

Jiran, N.S., Gholami, H., Mahmood, S., Saman, M.Z.M., Yusof, N.M., Draskovic, V., Javovic, R. 2019. Application of Activity-Based Costing in Estimating the Costs of Manufacturing Process. Transformations in Business \& Economics, Vol. 18, No 2B (47B), 839-860.

Kovalev, V. 2015. Financial management. Theory and practice. Moscow: Prospect, 104 p.

Limp, A., Loureiro Rezende, A., Versian, A. 2018. Customer relationships and interdependences in the internationalization process of the firm. RAUSP Management Journal, 1(53), 1151-1168. https://doi.org/10.1016/j.rauspm.2017.10.001

Neculaesei, A.N., Tatarusanu, M., Anastasiei, B., Dospinescu, N., Bedrule Grigoruta, M.V., Ionescu, A.M. (2019). A Model of the Relationship between Organizational Culture, Social Responsibility and Performance. Transformations in Business \& Economics, Vol. 18, No 2A (47A), pp.489-509.

Official site of Eurostat. 2019. www.ec.europa.eu/eurostat

Official site of JSC "National Managing Holding" Baiterek "for 2004-2023. https://baiterek.gov.kz/ru/

Official site of the Committee on Statistics of the Ministry of National Economy of the Republic of Kazakhstan. http://www.stat.gov.kz

Official site of the Development Bank of Kazakhstan. 2020. https://kdb.kz/

Polikarpov, K. 2018. Management of enterprises of certain industries in the context of international instability. Bulletin of SPbGAU, 2 (51), 225-230.

Rakhimbaev, A., Mikhel, E. 2016. Corporate finance. Almaty: LEM, 464 p.

Savitskaya, G. 2013. Analysis of the economic activity of the enterprise. Minsk: New knowledge, 688 p.

Shiryaeva, Yu., Pertseva, L., Lapshina, E., Lapshin, E. 2017. Some approaches to assessing the innovative development of an enterprise. Creative Economy, 11 (8), 855-862. https://doi.org/10.18334 / ce.11.8.38207.

Soldatova, M., Lazarenko, L., Stepanova, O. 2015. Monitoring of the activity of industrial enterprises at the present stage. Fundamental research, 2(11), 2432-2435. http://uecs.ru/ekonomika-prirodopolzovaniyz/item/4916-2018-05-16-07-17-01

Tepman, L. 2016. Investment Risk Management. Moscow: UNITI, 215 p.

Tretyakova, T., Alferova, A. 2016. Improving the methodological tools for assessing the sustainable development of industrial enterprises. Economic Analysis: Theory and Practice, 9(17), 86-99. http://www.fin-izdat.ru/journal/analiz/.

Turmanidze, T. 2015. Financial management. Moscow: UNITI, 247 p.

Yemelina, N., Omarova, A. 2018. Modelling of Sustainable Development. Journal of Environmental Management and Tourism, 1(25), 2018: 67-74. https://doi.org/10.14505//jemt.v9.1(25).15 


\section{ENTREPRENEURSHIP AND SUSTAINABILITY ISSUES}

ISSN 2345-0282 (online) http://jssidoi.org/jesi/

2020 Volume 8 Number 2 (December)

http://doi.org/10.9770/jesi.2020.8.2(70)

Make your research more visible, join the Twitter account of ENTREPRENEURSHIP AND SUSTAINABILITY ISSUES:@Entrepr69728810

Zhakisheva, K. 2018. Monitoring the financial status of enterprises in the agricultural sector. Journal of Applied Economic Sciences, 8 (62), 105-113.https://www.kaznu.kz/content/files/pages/folder21021/\%D0\%A1\%D0\%BA\%D0\%BE\%D0\%BF\%D1\%83D1\%81\%202018.pdf

Zhuravlyov, V., Khudyakova, T., Varkova, N., Aliukov, S., Shmidt S. 2019. Improving the Strategic Management of Investment Activities of Industrial Enterprises as a Factor for Sustainable Development in a Crisis. Sustainability. 11 (31), 6667-6678. https://doi.org/10.3390 / $\underline{\mathrm{su} 11236667}$

Ainur KARIPOVA is PhD of L.N. Gumilyov Eurasian National University, Nur-Sultan, Kazakhstan.Research interests: small and medium business, innovations, investments.

ORCID ID: orcid.org/0000-0003-4376-9074

Gulmira KABDULLINA is Doctor of Economic Sciences, Professor of South Ural State University, Russian Federation. Research interests: small and medium business, innovations, investments.

ORCID ID: orcid.org/0000-0002-0215-150

Gizat KENESHEVA is PhD student of Karaganda Economic University of Kazpotrebsoyuz, Karaganda, Kazakhstan. Research interests: small and medium business, innovations, investments.

ORCID ID: orcid.org/0000-0003-2928-8928

Madina TURSUMBAEVA is Doctor of Economic Sciences, Professor of Kazakh University of Economics, Finance and International Trade, Nur-Sultan, Kazakhstan. Research interests: finance, taxes, investments, budget, credit.

ORCID ID: orcid.org/0000-0001-7776-6221

Saltanat KAPYSHEVA - Candidate of Economic Sciences, Associate Professor of Kazakh University of Economics, Finance and International Trade, Nur-Sultan, Kazakhstan. Research interests: small and medium business, innovations, investments. ORCID ID: orcid.org/0000-0002-0916-4752

Zhanna NURGALIEVA - Candidate of Economic Sciences, Associate Professor of Kazakh University of Economics, Finance and International Trade, Nur-Sultan, Kazakhstan.

Research interests: small and medium business, innovations, investments.

ORCID ID: orcid.org/0000-0003-2652-7989

Copyright (C 2020 by author(s) and VsI Entrepreneurship and Sustainability Center

This work is licensed under the Creative Commons Attribution International License (CC BY).

http://creativecommons.org/licenses/by/4.0/

(c) (i) Open Access 